\title{
Potensi Reservoir Batupasir Formasi Ngimbang dan Interval Umur pra-Tersier Area Silaen-10, Sub-Cekungan Kangean, Cekungan Jawa Timur Utara
}

\author{
Michael Silaen $^{1}$, Yoga Aribowo $^{1}$, Reddy Setyawan ${ }^{1 *}$ \\ ${ }^{1}$ Departemen Teknik Geologi, Fakultas Teknik, Universitas Diponegoro
}

\begin{abstract}
Abstrak
Salah satu cekungan sedimen yang telah banyak dilakukan kegiatan eksplorasi minyak dan gas bumi adalah Cekungan Jawa Timur Utara. Cekungan ini memiliki sistem petroleum yang kompleks dan berbeda-beda untuk setiap Sub Cekungan. Berdasarkan penilitian terdahulu di Cekungan Jawa TimurUtara, diperlukan kajian lebih lanjut terhadap Formasi Ngimbang dan pra-Ngimbang untuk dapat menemukan prospek baru. Penelitian ini bertujuan untuk mengetahui stratigrafi dan persebaran batuan, mengetahui nilai properti batuan dari hasil perhitungan petrofisika, dan menentukan area prospek baru. Data yang digunakan mencakup dua sumur, yaitu sumur Silaen-1 dan Silaen 3, dan data seismik 3D. Empat marker yang digunakan dalam picking horison, yaitu R2, R1 (top dan bottom), dan SB praTersier. Hasil analisis data sumur menunjukkan pada sumur Silaen-1 tersusun dari perlapisan batupasir, batugamping, dan shale berseling dengan batubara, sedangkan sumur Silaen-3 tersusun atas litologi yang sama dengan Silaen-1, tetapi tanpa batugamping. Perhitungan petrofisika pada sumur Silaen-1 menunjukkan nilai rerata porositas efektif 27\%; Vshale 0,23; dan saturasi air $80 \%$, sedangkan Sumur Silaen-3 memiliki nilai rerata porositas efektif 24\%; Vshale 0,05; dan saturasi air 82\%. Penentuan area prospek terbaru menggunakan kombinasi play, peta struktur kedalaman, dan juga sebaran porositas efektif. Berdasarkan ketiga parameter tersebut, ada tiga horison yang layak untuk potensi, yaitu top R1, bottom R1, dan SB pra-Tersier. Horison R1 terdapat dua area prospek baru untuk dilakukan eksploitasi, sedangkan horison SB pra-Tersier memiliki empat area prospek terbaru.

Kata kunci: Analisis Petrofisika; Cekungan Jawa Timur-Utara; Interpretasi Litologi; Penentuan Area Propek.
\end{abstract}

\begin{abstract}
The North East Java Basin has interesting geological conditions. Based on the research carried out in the East-North Java Basin, further studies are needed on the Ngimbang and pre-Ngimbang Formation to find new hydrocarbon prospects. This study aims to determine the stratigraphy and distribution of rocks, to determine the value of rock properties based on petrophysical calculations, and determine the area of new prospects. The research location is in the Silaen-10 Area, Kangean Block, Kangean Sub Basin. The data used in the study used well data (Silaen-1 and Silaen 3) and 3D seismik data. Four markers used in horizon picking, namely R2, RI (top and bottom), and pre-Tertiary SB. The results of lithological interpretation of well data analysis found that the Silaen-1 well was composed of sandstone, limestone and shale layers interspersed with coal, while the Silaen-3 well was composed of the same lithology as Silaen-1, but there was no limestone. Petrophysical calculations on the Silaen-1 obtained average value of effective porosity of 27\%; Vshale of 0.23 ; and water saturation of $80 \%$, while the Silaen-3 obtained average value of effective porosity of 24\%; Vshale of 0.05; and water saturation of $82 \%$. To determine the latest prospect area using a combination of play, depth structure maps, and also the distribution of effective porosity. Based on the three parameters, here are three feasible horizons for potential, top R1; bottom R1; and pre-Tertiary SB. Horizon RI has two new prospect areas, while the pre-Tertiary $S B$ horizon has four new prospect areas.
\end{abstract}

Keywords: East-Java Basin, Lithology Interpretation, Petrophysics Analysis, Prospect Area Determination

\footnotetext{
*) Korespondensi: reddy@live.undip.ac.id

Diajukan : 2 Februari 2021

Diterima : 30 Juni 2021

Diterbitkan : 31 Juli 2021
} 


\section{PENDAHULUAN}

Cekungan Jawa Timur merupakan cekungan yang sudah banyak dilakukan kegiatan eksplorasi minyak dan gas bumi. Cekungan Jawa Timur-Utara memiliki lima sistem petroleum yang berbeda-beda yaitu: NgimbangOK Ngrayong pada area Cepu Jawa Timur, Ngimbang-Ngimbang pada area offshore Kangean sebelah utara pulau Bali, NgimbangKujung pada area Cepu dan Sub Cekungan Madura, Tersier-Miosen dengan komposisi sistem gas yang besar pada area Sub Cekungan Muriah, dan Tersier-Pliosen dengan sistem kaya akan gas biogenik pada area southeast Madura yang berbatasan dengan utara Bali (Doust dan Noble, 2008). Salah satu Formasi yang menarik dan dijadikan target adalah Formasi Ngimbang. Formasi Ngimbang dapat berperan sebagai batuan sumber dan reservoir.

Survei seismik 2D terbaru yang telah dipublikasikan oleh Satyana (2016) menggambarkan rekonstruksi terbaru tektonostratigrafi dari umur Paleozoikum hingga Kuarter. Hasil penampang seismik terbaru tersebut memperlihatkan bahwa masih terdapat susunan batuan yang diinterpretasi sebagai batuan sedimen pada umur Mesozoikum. Bagian bawah Formasi Ngimbang dipisahkan oleh sequence boundary yang memisahkan endapan sedimen Mesozoikum dengan Kenozoikum.

Maulin dkk. (2012) melakukan penelitian pada Cekungan Jawa Timur Utara berdasarkan suvei seismik. Penelitian mereka bertujuan untuk mengembangkan teori tektonik yang bekerja pada Cekungan ini. Hasil penelitian mereka menunjukkan bahwa ada tektonik inversi yang sangat berpengaruh dalam pembentukan struktur patahan dan lipatan yang sangat kompleks dengan oritentasi arah Timur-Barat. Pembentukan struktur inversi ini terjadi pada umur Tersier, kala Pliosen.

Berdasarkan penilitian yang telah banyak dilakukan pada Cekungan Jawa Timur-Utara, diperlukan kajian lebih lanjut terhadap Formasi Ngimbang dan pra-Ngimbang untuk dapat melihat prospek baru dalam mencari hidrokarbon. Area penelitian terletak pada lokasi offshore pulau Kangean bagian selatan. Studi seismik menggunakan survei seismik 3D.

Tujuan dari penelitian ini adalah untuk mengetahui stratigrafi, persebaran litologi, struktur geologi, dan indikasi dalaman (depocenter) yang menjadi tempat pembentukan dan pematangan hidrokarbon, mengetahui nilai porositas efektif, saturasi air, dan Vshale pada zona reservoir, dan menentukan potensi alternatif hidrokarbon pada area penelitian.

\section{Geologi Regional}

Daerah penelitian termasuk pada Formasi Ngimbang dan pra-Ngimbang. Menurut Philips dkk. (1991) Formasi pra-Ngimbang didominasi batupasir dan batulempung pasiran berumur Paleosen hingga Eosen Tengah diendapkan pada alluvial. Formasi Ngimbang dibedakan menjadi Ngimbang Klastik, Ngimbang Karbonat, dan Ngimbang Shale. Ngimbang Klastik didominasi oleh batupasir yang diendapakn pada lingkungan terrestrial berumur Eosen Akhir, sedangkan Ngimbang Karbonat disusun oleh batugamping yang diendapkan di shallow marine berumur Eosen Akhir, dan Ngibang Shale disusun oleh shale diendapkan pada deep outer shelf hingga bathyal umur Eosen Akhir.

Struktur geologi yang terdapat pada Cekungan Jawa Timur Utara merupakan patahan geser yang memanjang dari Utara Lombok hingga Madura dan disebut sebagai patahan RMKS (Rembang, Madura, Kangean, dan Sakala). Selain patahan, struktur geologi yang bekerja yaitu zona antiklinorium. Patahan RMKS dan zona antiklinorium memiliki orientasi arah yang sama yaitu Barat-Timur. Sribudiyani dkk (2003) membagi tiga bagian evolusi tektonik regional pulau Jawa, yaitu Kapur Akhir-Tersier (70-35 Ma), OligosenAwal Miosen (35-20 Ma), dan Akhir MiosenKuarter (7-2 Ma).

Emmet dan Bally (1996) melakukan penelitian terhadap kondisi tektonik pada Cekungan Jawa Timur-Utara. Hasil analisa mereka menunjukkan adanya pengaruh tektonik menyebabkan banyaknya terbentuk patahan dan lipatan yang kompleks pada Cekungan tersebut.

\section{METODOLOGI}

Dalam penelitian ini metode yang digunakan adalah pengumpulan data sumur dan data seismik, serta data sekunder untuk mendukung dalam penelitian. Penelitian ini tidak menggunakan data batuan inti (core).

Data sumur yang digunakan sebanyak dua sumur yaitu Silaen-1 dan Silaen-3. Kedua sumur tersebut memiliki data log berupa Log gamma ray, resistivitas, densitas, neutron, dan sonic. Secara umum analisis yang dilakukan dalam 
penelitian ini adalah analisis petrofisika, seismik, analisis atribut seismik, Analisis metode inversi, pembuatan peta sebaran porositas efektif, dan inventarisasi area prospek.

Data log tersebut digunakan untuk melakukan penentuan litologi dan analisis petrofisika. Analisis petrofisk mencakup analisis mencari nilai volume shale, nilai porositas batuan dan nilai saturasi air.

Analisis seismik pada penelitian ini menggunakan data survei 3D yang memiliki luasan berkisar $400 \mathrm{~km}^{2}$. Ada sebanyak 76 line seismik yang diinterpretasi dalam penelitian ini, yakni ada 57 line seismik crossline dan 19 lintasan seismik inline (Gambar 1). Dalam analisis seismik tahapan pertama yang dilakukan adalah melakukan picking horison dan patahan. Analisis seismik merupakan proses pengerjaan untuk menginterpretasi bawah permukaan dan bertujuan untuk memodelkan bawah permukaan sehingga mendapatkan gambaran stratigrafi, struktur patahan/lipatan, dan juga sistem petroleum. Ada tahapan yang perlu dilakukan dalam analisis seismik sebelum sampai pada menginterpretasi bawah permukaan. Tahapan tersebut berupa Well to Seismic Tie, penentuan marker stratigrafi yang akan dianalisis, penentuan arah struktur regional penelitian, dan membuat peta struktur waktu serta peta struktur kedalaman.

Tahap proses well Seismic Tie merupakan tahapan untuk mengikat sumur terhadap seismik. Pengikatan data sumur perlu dilakukan untuk menginterpretasi keberadaan suatu formasi pada seismik dengan baik. Selain itu perlunya proses tersebut dilakukan karena domain seismik berbeda dengan data sumur, seismik menggunakan domain waktu sedangkan sumur menggunakan domain kedalaman. Proses well to Seismic Tie memerlukan data log berupa log densitas dan log sonic. Kedua log ini nantinya akan dikonvolusikan dengan suatu gelombang disebut sebagai wavelet (dengan pemilihan berbagai jenis fase). Hasil konvolusi dengan wavelet seismogram sintetik. Seismogram sintetik merupakan seismik buatan yang sudah terkoreksi dengan data log sehingga hasilnya akan lebih baik dari seismik data semula. Setelah seismogram sintetik terbentuk tahap berikutnya ialah mengkorelasikannya dengan seismik semula. Hasil korelasi akan membawa dampak perubahan terhadap marker sumur yang tampak pada seismik.

Setelah tahapan well Seismic Tie langkah berikutnya adalah menentukan marker yang akan dijadikan sebagai picking horison. Selain melakukan picking horison, tahapan yang dilakukan berikutnya yaitu picking patahan. Patahan sangat penting karena dalam memodelkan suatu reservoir patahan sangat berperan penting dalam proses migrasi. Tahapan setelah melakukan tahapan picking horison dan patahan yaitu membuat peta waktu. Pada peta struktur waktu ini masih dalam bentuk model yang belum memiliki patahan sehingga diperlukan proses untuk membuat model patahan pada peta struktur waktu. Model dari patahan pada peta waktu disebut sebagai peta struktur waktu (time structure map).

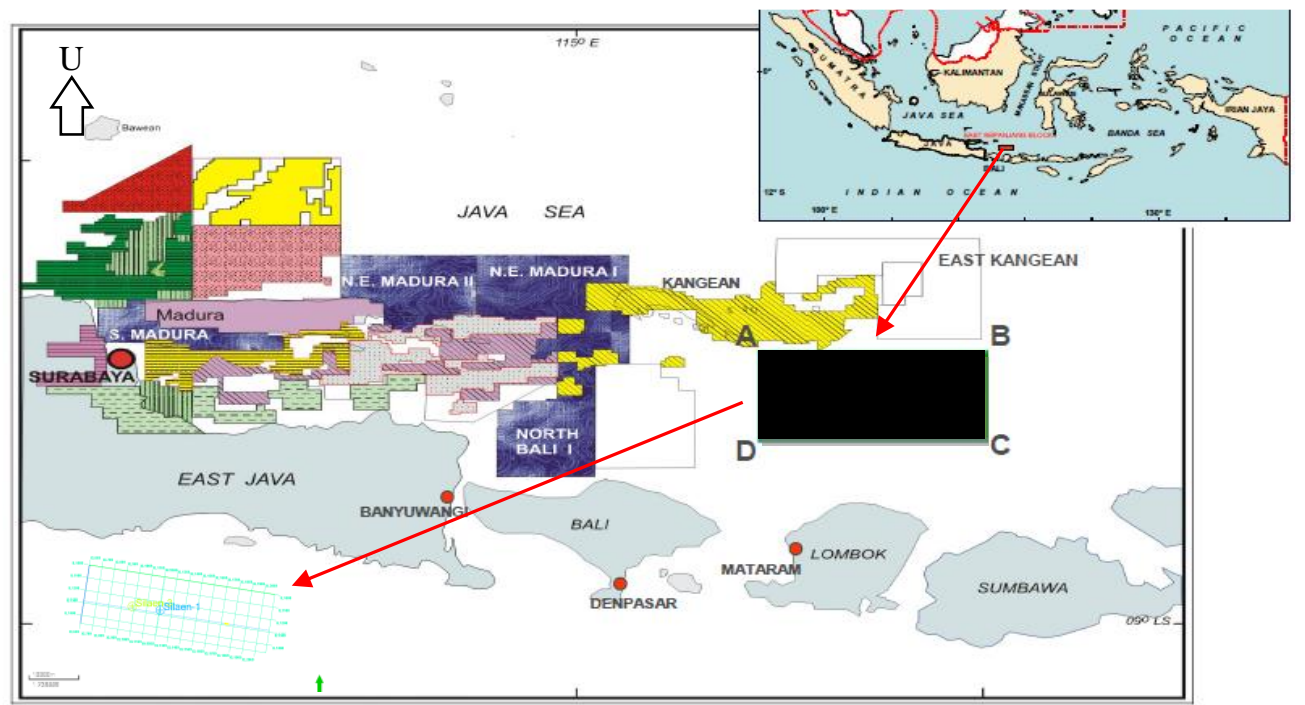

Gambar 1. Area lokasi penelitian dan peta dasar lintasan seismik (inset kiri bawah). 
Peta struktur waktu masih memiliki domain dalam waktu, sehingga perlu langkah untuk melakukan konversi dari waktu menjadi kedalaman dengan menggunakan data checkshot. Data tersebut sangat penting karena berisi waktu dan kedalaman yang didapatkan bersamaan di sumur. Setelah memasukkan data checkshot maka peta struktur waktu yang sudah didapatkan sebelumnya akan menjadi peta struktur kedalaman (depth structure map).

Setelah tahapan tersebut, untuk menduga adanya indikasi keterdapatan hidrokarbon menggunakan atribut seismik berupa rms amplitude. Kemudian untuk dapat melihat nilai dari model reservoir dilakukan permodelan menggunakan metode inversi dari hasil property porositas sehingga model reservoir yang sudah tergambar akan terlihat nilai dari porositas yang didapatkan. Hasil akhir dari analisis tersebut yaitu inventarisasi area propek model reservoir.

\section{HASIL}

\section{Analisis Petrofisika}

Formasi yang dijadikan sebagai fokus penilitian merupakan mulai dari Formasi Ngimbang, praNgimbang, dan pra-Tersier. Formasi pra-Tersier belum ada ditembus oleh sumur baik eksplorasi maupun produksi, sehingga untuk interpretasi jenis/tipe litologi dan menghitung nilai petrofisika hanya mencakup berdasarkan pembacaan data log pada Formasi Ngimbang hingga pra-Ngimbang. Formasi Ngimbang pada sumur Silaen-1 diinterpretasi berada pada kedalaman antara 2.320 meter hingga 3.086 meter, sedangkan pada Sumur Silaen -3 diinterpretasi berada pada kedalaman antara 2.500 meter hingga 3.447 meter.

Hasil pembacaan nilai log menunjukkan Sumur Silaen-1 terdapat litologi berupa shale berseling dengan batubara, batupasir, batugamping (Gambar 2), sedangkan untuk sumur Silaen-3 juga memiliki tipe litologi yang sama, yakni terdapat susunan litologi berupa shale berseling dengan batubara, dan batupasir tetapi tidak terdapat batugamping.

Berdasarkan analisis petrofisika menggunakan data log pada sumur, didapatkan beberapa zona yang diinterpretasi sebagai reservoir. Pada Sumur Silaen-1 terdapat tiga zona yang diinterpretasi sebagai reservoir pada kedalaman $2.600 \mathrm{~m}$ hingga $2990 \mathrm{~m}$, sementara
Sumur Silaen-3 terdapat tiga zona yang diinterpretasi sebagai reservoir pada kedalaman $3.100 \mathrm{~m}$ hingga $3.300 \mathrm{~m}$. Hasil perhitungan analisis petrofisika pada kedua sumur yakni, Sumur Silaen-1 (Gambar 3) memiliki nilai Vshale sebesar 0,23 porositas efektif bernilai $27 \%$, dan saturasi air bernilai $80 \%$ sedangkan Sumur Silaen-3 memiliki nilai Vshale sebesar 0,05 porositas efektif bernilai $24 \%$, dan saturasi air bernilai $82 \%$.

\section{Analisis Seismik}

Korelasi antara seismogram sintetik dengan seismik semula bernilai 0,8 dengan timeshift sebesar $0 \mathrm{~ms}$. Bila dilihat dari nilai korelasi ini termasuk sudah akurat antara pengikatan sumur terhadap penampang seismik.

Setelah tahapan well Seismic Tie, langkah berikutnya adalah menentukan marker yang akan dijadikan sebagai picking horison Dalam penelitian ini terdapat empat marker yang hasil dari picking horison yaitu horison R2, Top R1, Bottom R1, dan SB pra-Tersier (Gambar 4).

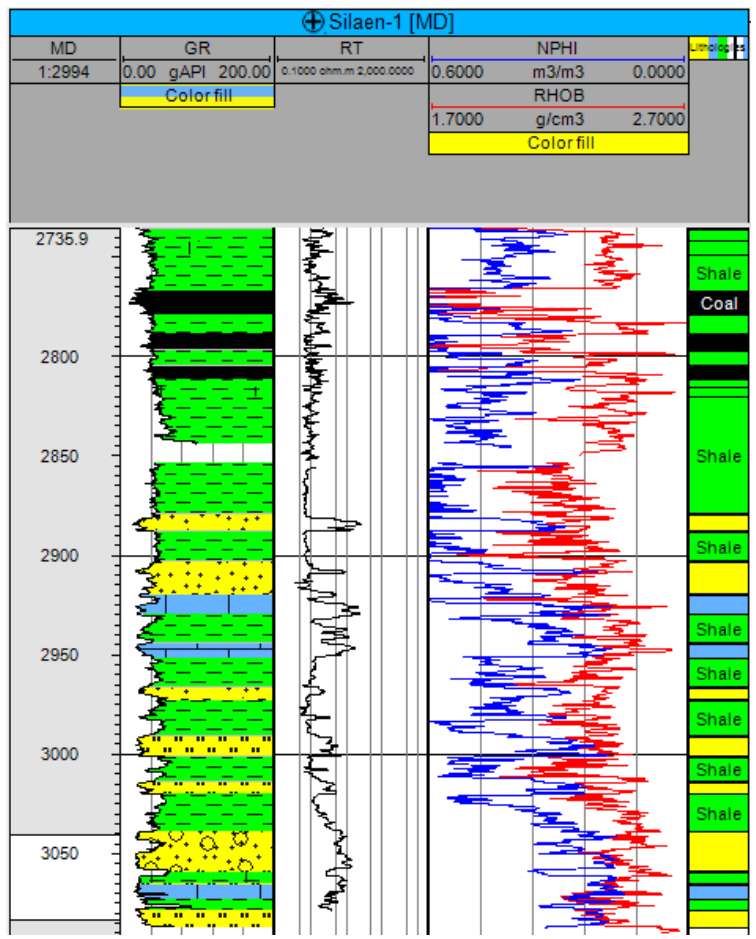

Gambar 2. Interpretasi litologi Sumur Silaen-1 pada kedalaman $\pm 2.700 \mathrm{~m}$ hingga $\pm 3.100 \mathrm{~m}$. 


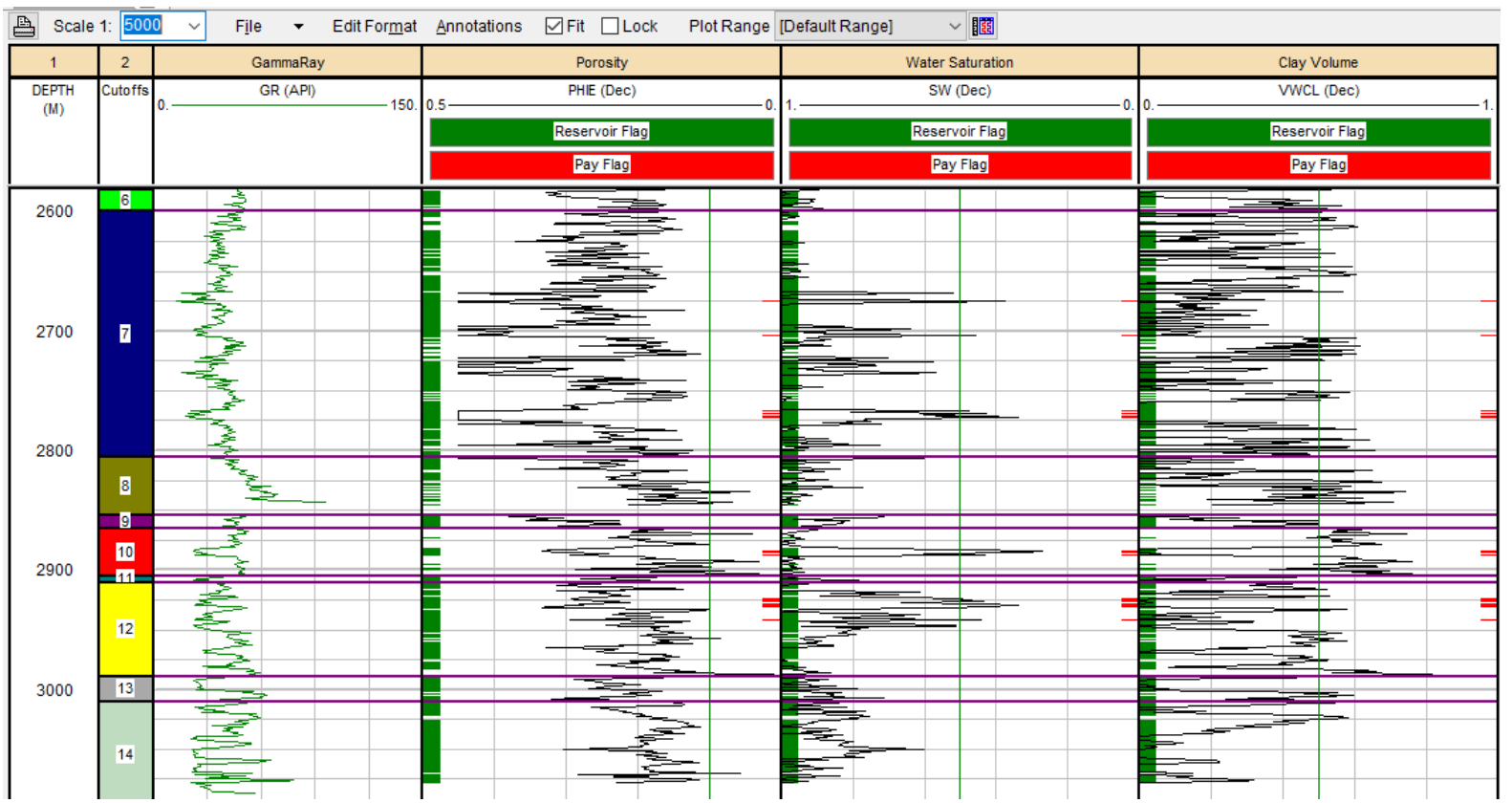

Gambar 3. Hasil analisis petrofisika dalam bentuk log pada Sumur Silaen-1 pada kedalaman $2600 \mathrm{~m}-3.100 \mathrm{~m}$.

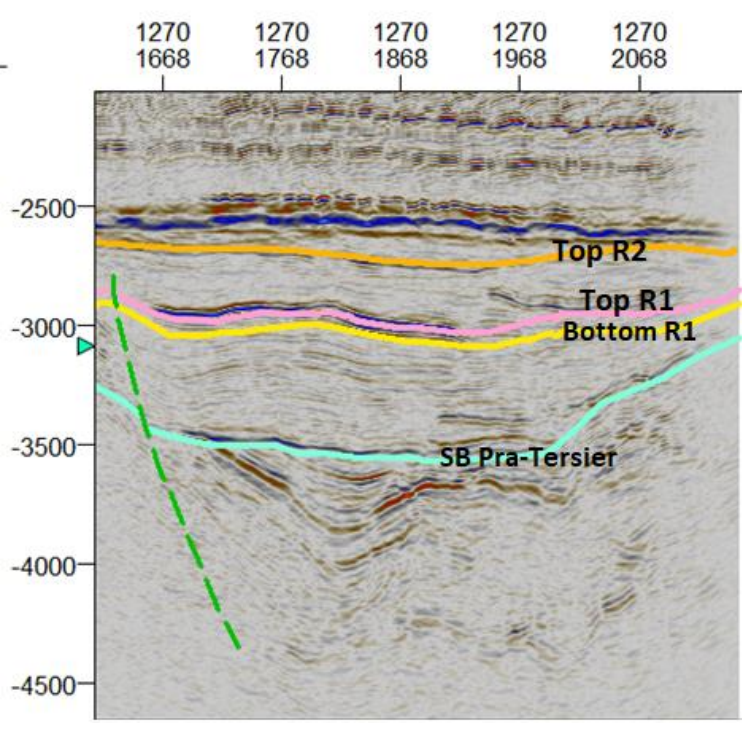

Gambar 4. Empat marker yang hasil dari picking horison.

\section{Analisis Atribut Seismik}

Salah satu cara sederhana untuk melihat keberadaan hidrokarbon di penampang seismik adalah menggunakan atribut seismik berupa amplitudo. Sinyal amplitudo dapat merekam keberdaan hidrokarbon khususnya gas bumi. Rekaman sinyal amplitudo akan merekam keterdapatan gas bumi yang akan ditunjukkan dengan sebuah anomali. Anomali tersebut berupa brightspot. Hasil dari pengerjaan amplitudo rms yang dikerjakan pada seismik yakni keberadaan anomali brightspot paling banyak muncul di bagian closure dan bagian depocenter.

Kenampakan brighspot ditandai dengan warna yang relatif jingga tersebut. Arti kenampakan brighspot pada salah satu horison R2 tersebut menunjukkan nilai amplitudo daerah itu relatif tinggi. Kenampakan tersebut diinterpretasikan sebagai area yang menarik karena kondisi fisis batuan berupa porositas relating tinggi, volume shale dan saturasi yang relatif rendah. Dari kenampakan tersebut mengindikasikan bahwa gas (Gambar 5) berada banyak pada bagian dalaman sebagai tempat terbentuknya dan akan bermigrasi ke bagian penutup (closure).

\section{Analisis Metode Inversi}

Pemodelan reservoir yang berikutnya adalah dengan menggunakan metode inversi untuk membuat model bawah permukaan yang mereprasentasikan litologi dan persebarannya dari data observasi pengukuran, dalam hal ini yaitu data well log. Dalam tahap memodelkan potensi reservoir menggunakan metode inversi, ada beberapa tahapan yang harus dikerjakan terlebih dahulu yakni mengerjakan analisis sensitivitas, membuat model awal Inversi, analisis pra inversi, dan membuat model inversi AI (Accoustic Impedance).

Tahapan analisis sensitivitas menggunakan crossplot log densitas, neutron, gamma ray, dan impedans. Crossplot pertama merupakan 


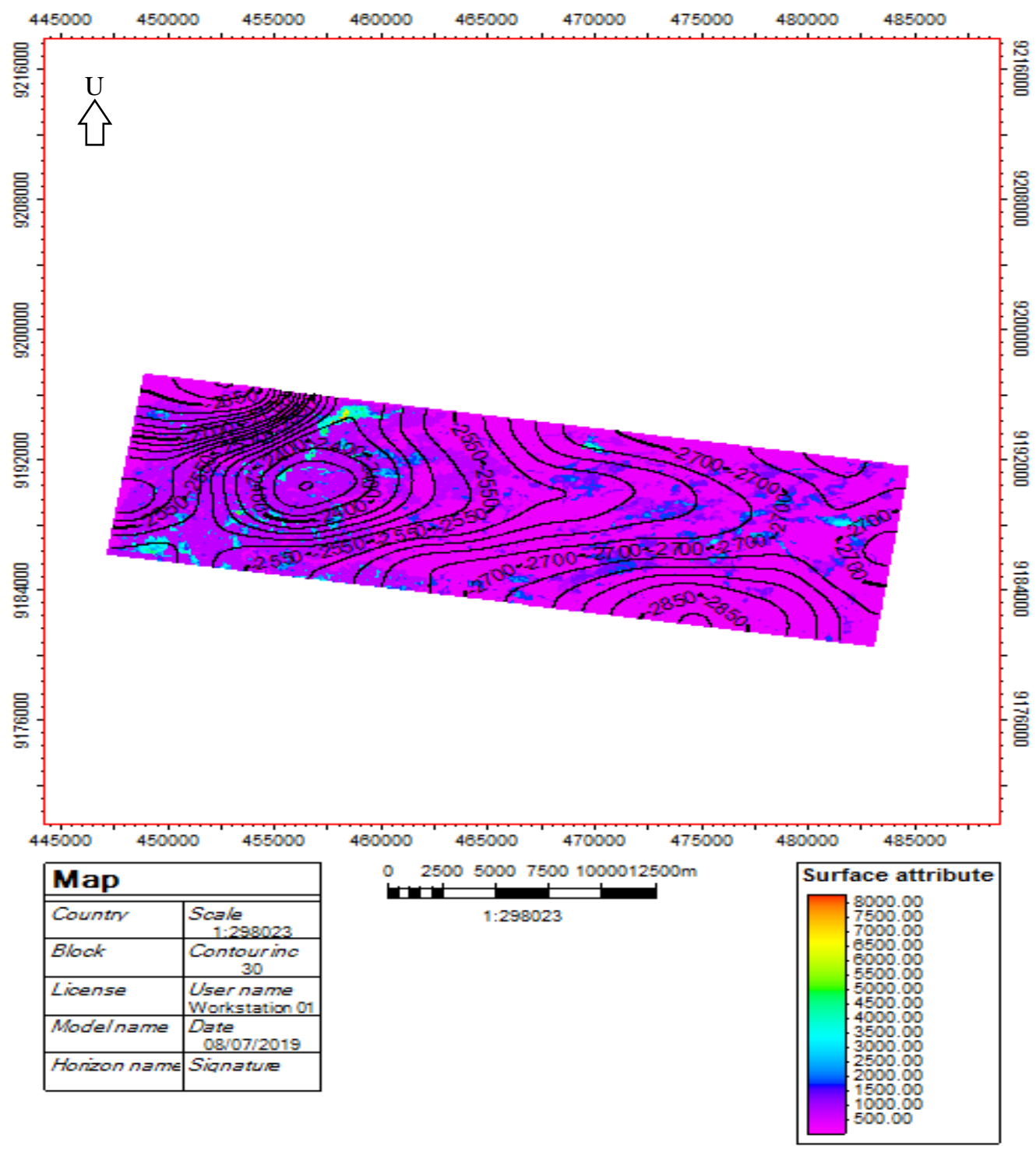

Gambar 5. Kenampakan brightspot pada surface atribut RMS amplitude horison R2.

hubungan antara log densitas, impedans, dan gamma ray, sedangkan xplot kedua merupakan hubungan antara log neutron, impedans, dan juga gamma ray. Tujuan dilakukannya xplot adalah untuk mengetahui hubungan antara pembacaan log dalam pengerjaan dengan zona yang diduga sebagai reservoir dan juga untuk mengetahui jenis litologi sebagai reservoir tersebut (Gambar 6).

Dari pembacaan tersebut, secara garis besar dapat dibedakan menjadi dua area, yang berwarna kuning dan berwarna abu-abu. Area yang berwarna kuning memiliki nilai densitas, impedans, dan gamma ray yang rendah. Dengan kondisi tersebut, kemungkinan litologinya adalah batupasir. Pada area yang berwarna abu- abu tersebut memiliki nilai densitas, nilai impedans, dan gamma ray tinggi. Jenis litologi dengan kondisi tersebut adalah shale. Untuk mendukung interpretasi litologi berdasarkan sifat fisis batuan tersebut, dapat dibaca menggunakan xplot pada log neutron, log gamma ray, dan juga impedans. Analisis ini dilakukan pada kedalaman yang sama untuk dapat menyebandingkan hubungan antara densitas dan neutron (Gambar 7).

Pada Gambar 6, dapat dilihat area yang sebelah kiri didominasi oleh nilai neutron yang relatif tinggi, sedangkan nilai impedans yang rendah dan juga nilai gamma ray yang rendah. Berdasarkan keadaan tersebut, dapat diinterpretasikan sifat fisis batuan di area 


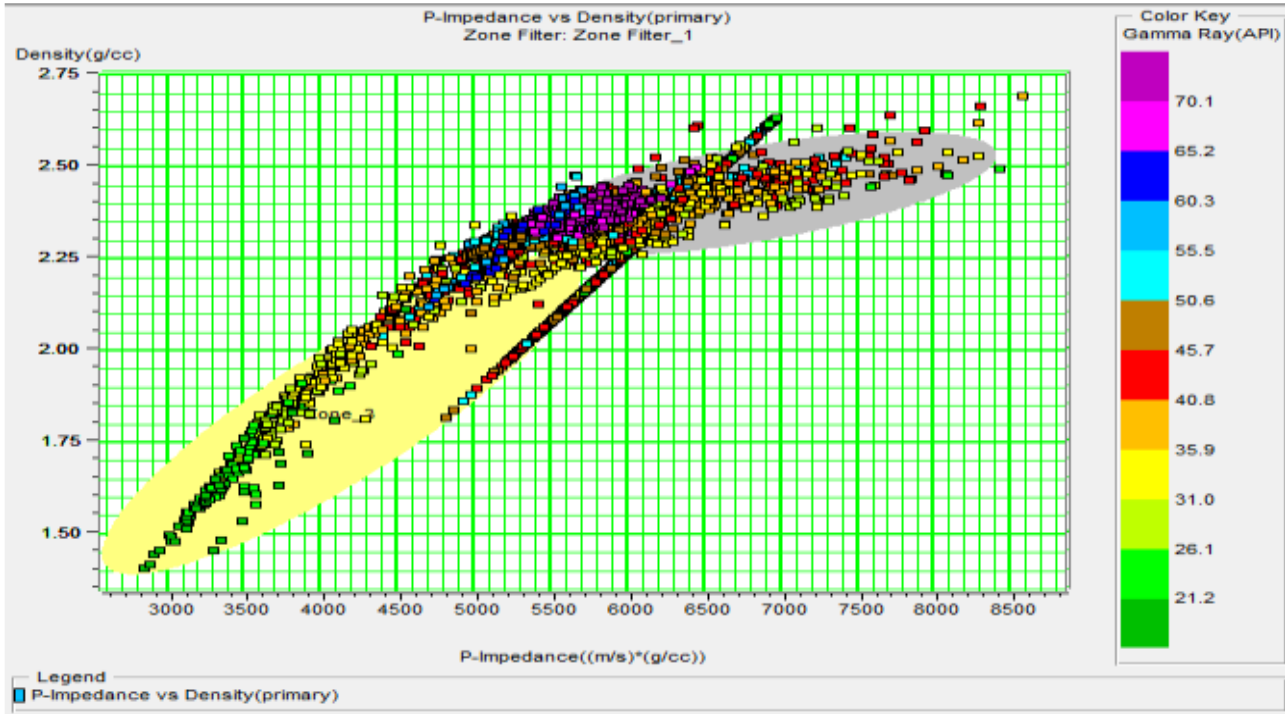

Gambar 6. Sensitivitas densitas sumur Silaen-1

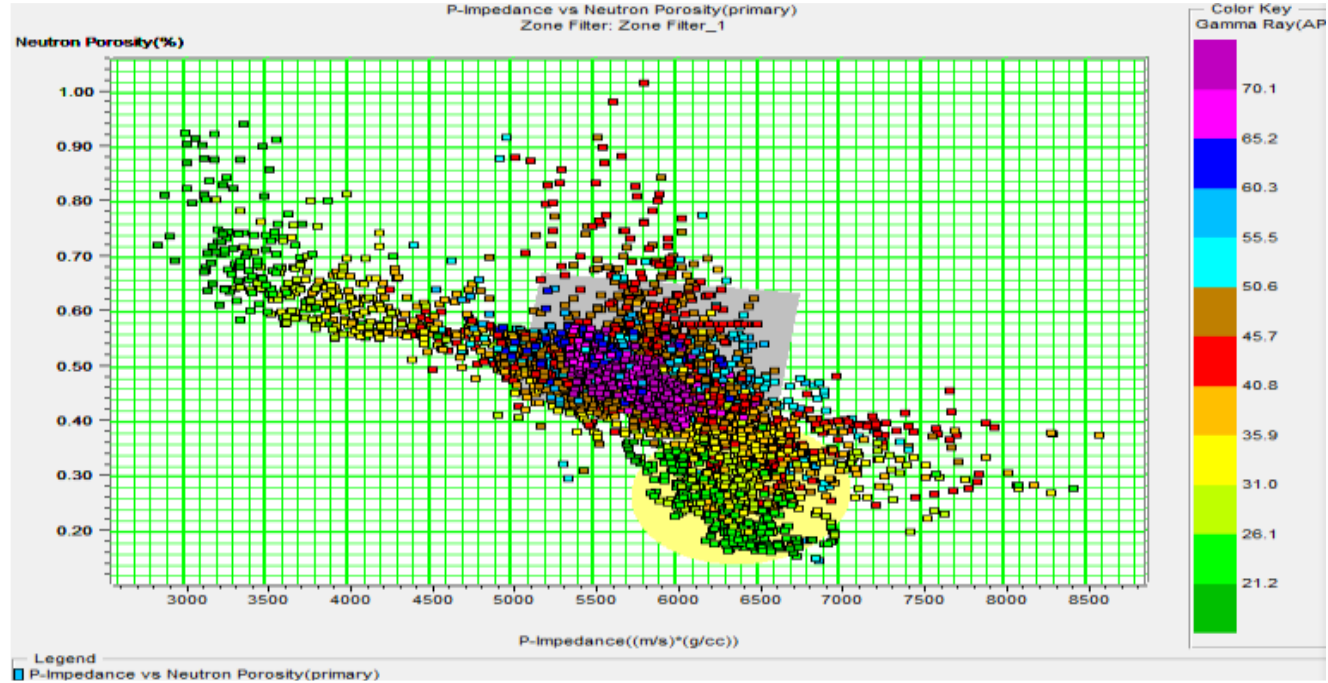

Gambar 7. Sensitivitas neutron sumur Silaen-1.

tersebut porositas relatif tinggi, namun porositas dalam pembacaan ini merupakan porositas total bukan porositas efektif. Di bagian kanan, dapat diihat nilai porositas cenderung menurun, didukung dengan nilai impedans yang relatif tinggi dan juga nilai gamma ray yang tinggi. Berdasarkan keadaan tersebut, sifat fisis batuan yang menggambarkan area itu merupakan rendah porositas.

Langkah selanjutnya ialah membuat model awal sebelum inversi yang menggambarkan keadaan bawah permukaan berdasarkan pembacaan impedans. Pada Gambar 8 dapat dilihat bagian yang berada pada horison picking memiliki nilai impedans yang relatif sedangrendah. Hal tersebut diinterpretasikan bahwa bagian horison tersebut merupakan litologi yang memiliki karakteristik densitas cenderung rendah. Karakteristik litologi tersebut dapat berupa batupasir yang diinterpretasikan sebagai zona reservoir.

Selanjutnya adalah melakukan analisis pra inversi yang bertujuan untuk membuat model berdasarkan hasil korelasi model awal inversi dengan nilai asli dari data observasi pengukuran well log. Tujuan dari tahapan ini adalah memiliki model yang bagus berdasarkan keadaan sifat fisis batuan. Kontrol kualitas model dapat dilihat dari nilai korelasi model. Semakin tinggi nilai korelasi, semakin mendekati sifat fisis asli batuan. 


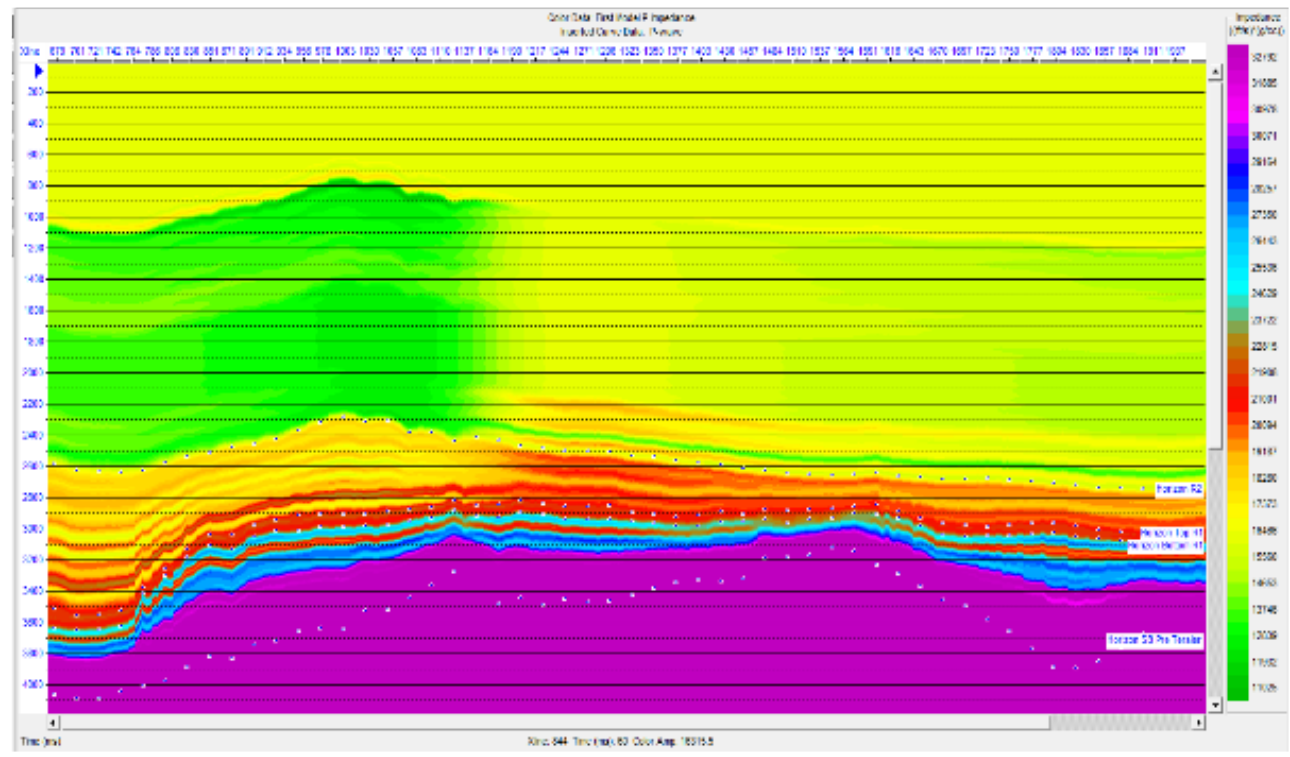

Gambar 8. Model awal inversi inline 1279

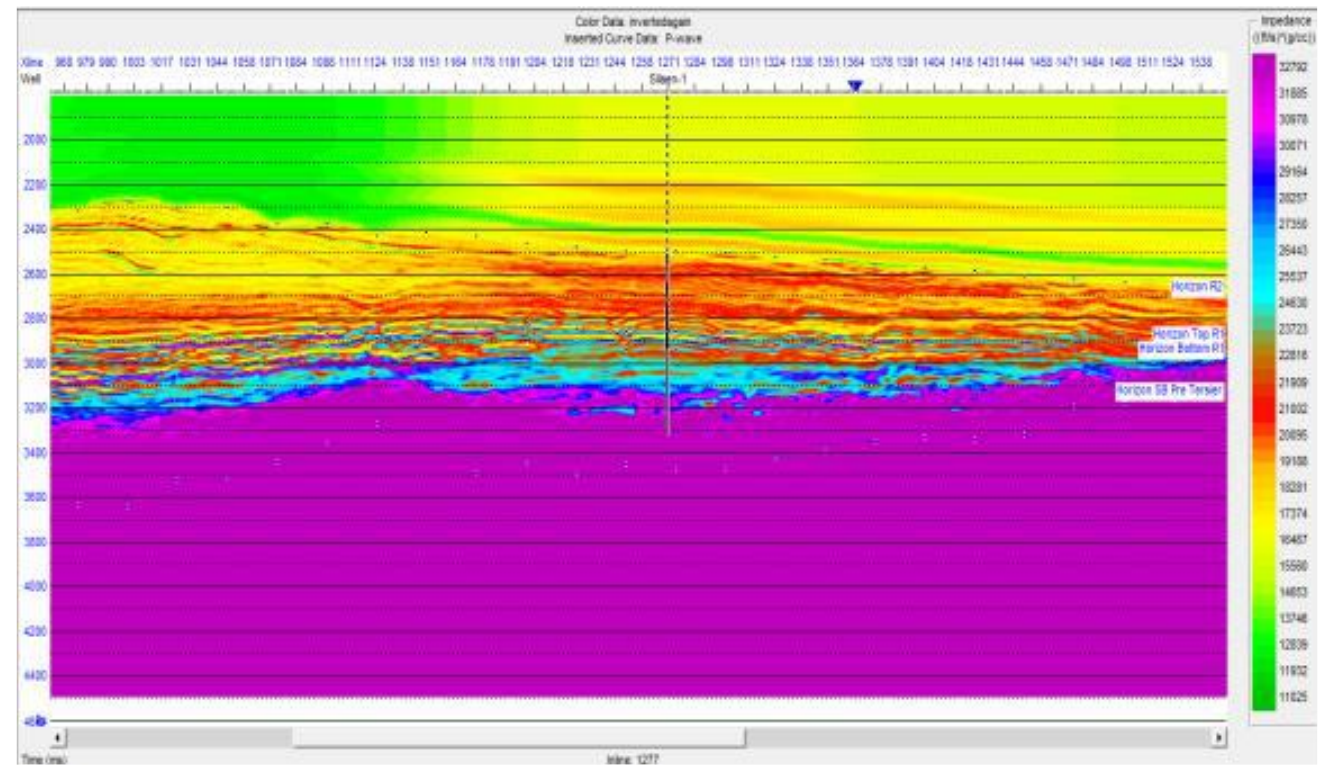

Gambar 9. Model based hasil inversi.

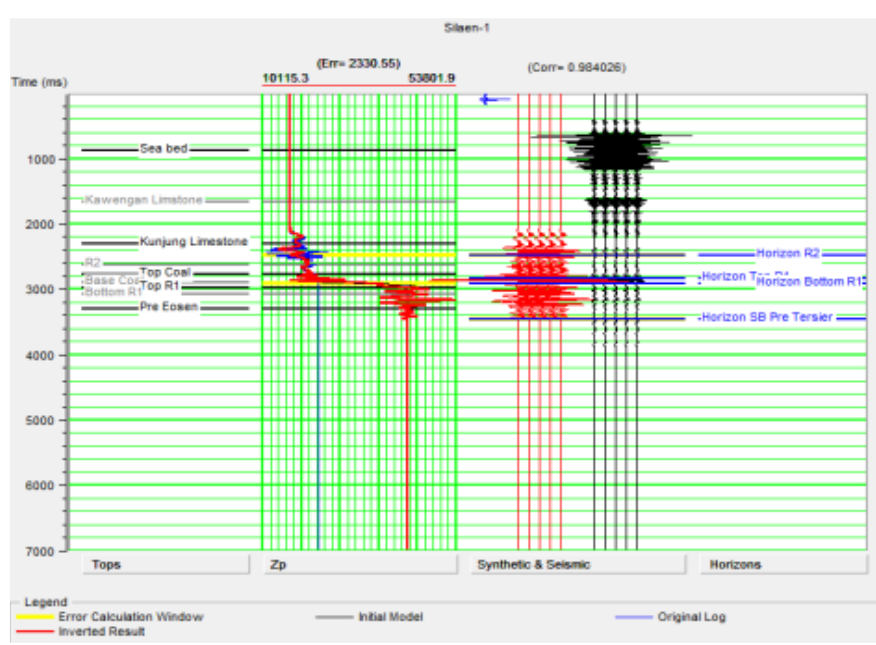

Gambar 10. Model Bandlimited 
Model based memiliki korelasi sebesar 0,91 (Gambar 10). Model based memiliki nilai korelasi yang cenderung tinggi karena baik digunakan pada target yang memiliki reflektifitas rendah. Setelah melakukan analisis pra inversi, langkah terakhir adalah memodelkan reservoir menggunakan metode inversi dengan domain dalam impedans.

Hasil model inversi tersebut dapat dibuat persebaran secara horisontal berdasarkan empat horison hasil picking. Dari keempat hasil slice atau persebaran secara lateral, nantinya akan dapat ditafsirkan area prospek pada setiap horison tersebut. Gambar 12 menunjukkan hasil irisan horison R2.

Berdasarkan hasil persebaran secara lateral pada horison R2, menunjukkan warna jingga, kuning, dan hijau muda. Semua area horison R2 dapat ditafsirkan sebagai area potensi baik karena parameter dalam AI yang dilihat adalah sifat fisik densitas dari batuan tersebut.

\section{Peta Sebaran Porositas Efektif}

Porositas efektif telah didapatkan dalam analisis petrofisika. Sebelum membuat peta sebaran porositas efektif, tahapan yang dilakukan adalah memasukkan log hasil perhitungan mendapatkan nilai porositas efektif ke dalam analisis seperti membuat analisis inversi. Setelah memasukkan $\log$ porositas efektif dalam pengerjaan, langkah berikutnya ialah menentukan area yang benarbenar prospek berdasarkan sifat fisik batuan dan juga keadaan geologi. Berdasarkan sifat fisik dan juga keadaan geologi batuan, area yang ditandai berada pada top R1 sampai bottom R1.

Berikutnya adalah tahap neural network untuk melihat korelasi keadaan sebenarnya dengan model hasil pengukuran. Garis biru pada Gambar 11 menunjukkan bahwa daerah yang sudah ditarget sebelumnya terletak dari horison top R1 hingga bottom R1. Bagian berwarna hitam yang berbentuk seperti log, merupakan data input dari log porositas efektif, dan bagian yang berwarna merah merupakan model log porositas efektif yang akan dikerjakan dalam pembuatan persebaran porositas tersebut. Apabila tampilan dari masing-masing sumur dari Gambar 13 menunjukkan korelasi yang tinggi antara model log yang dibuat dengan log asli pengukuran sehingga dengan korelasi yang tinggi ini dapat membuat model yang komprehensif (Gambar 9).

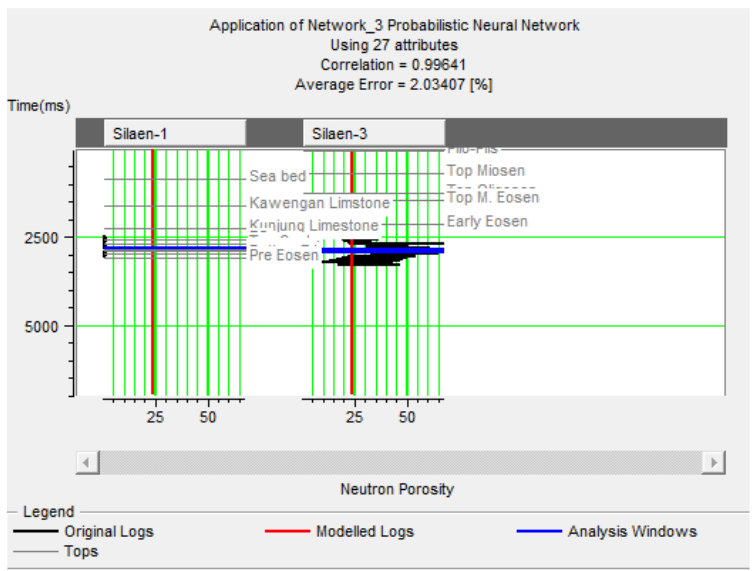

Gambar 11. Tahapan neural network.

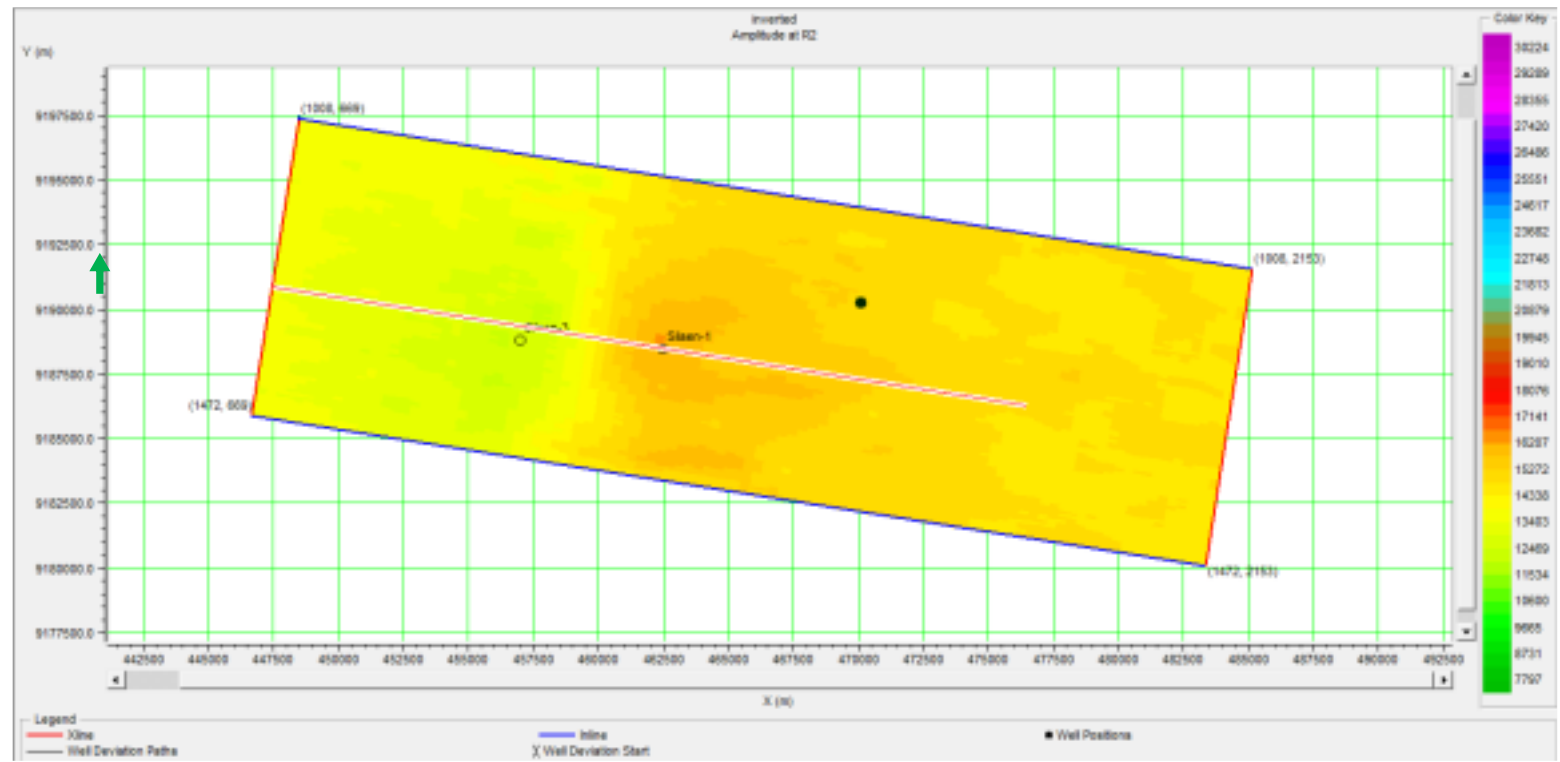

Gambar 12. Hasil irisan horison R2. 
Langkah selanjutnya yaitu membuat analisis sebaran porositas efektif pada kedua sumur tersebut. Langkah ini sama dengan melakukan analisis AI pada tahap sebelumnya. Gambar 14 menunjukkan hasil analisis sebaran porositas efektif pada lintasan seismik inline 1271 yang melewati sumur Silaen-1.

Pada Gambar 14 dapat dilihat bahwa warna ungu memiliki angka porositas efektif yang tinggi mencapai 32 (dalam satuan persen), sedangkan warna hijau relatif rendah mencapai 25 (dalam satuan persen. Sebaran lateral porositas efektif yang digunakan untuk melihat angka porositas efektif sepanjang horison tersebut. Hasil irisan persebaran porositas efektif dapat dilihat pada Gambar 14.

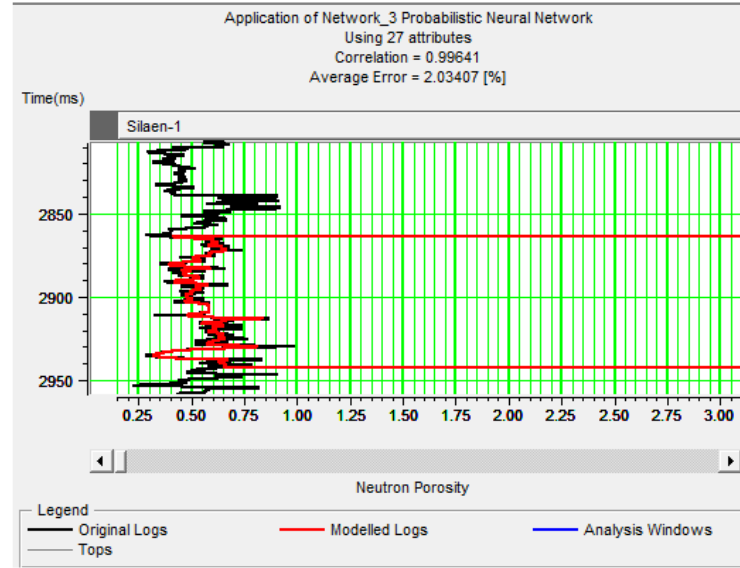

Gambar 9. Perbesaran skala hasil korelasi sumur Silaen-1.

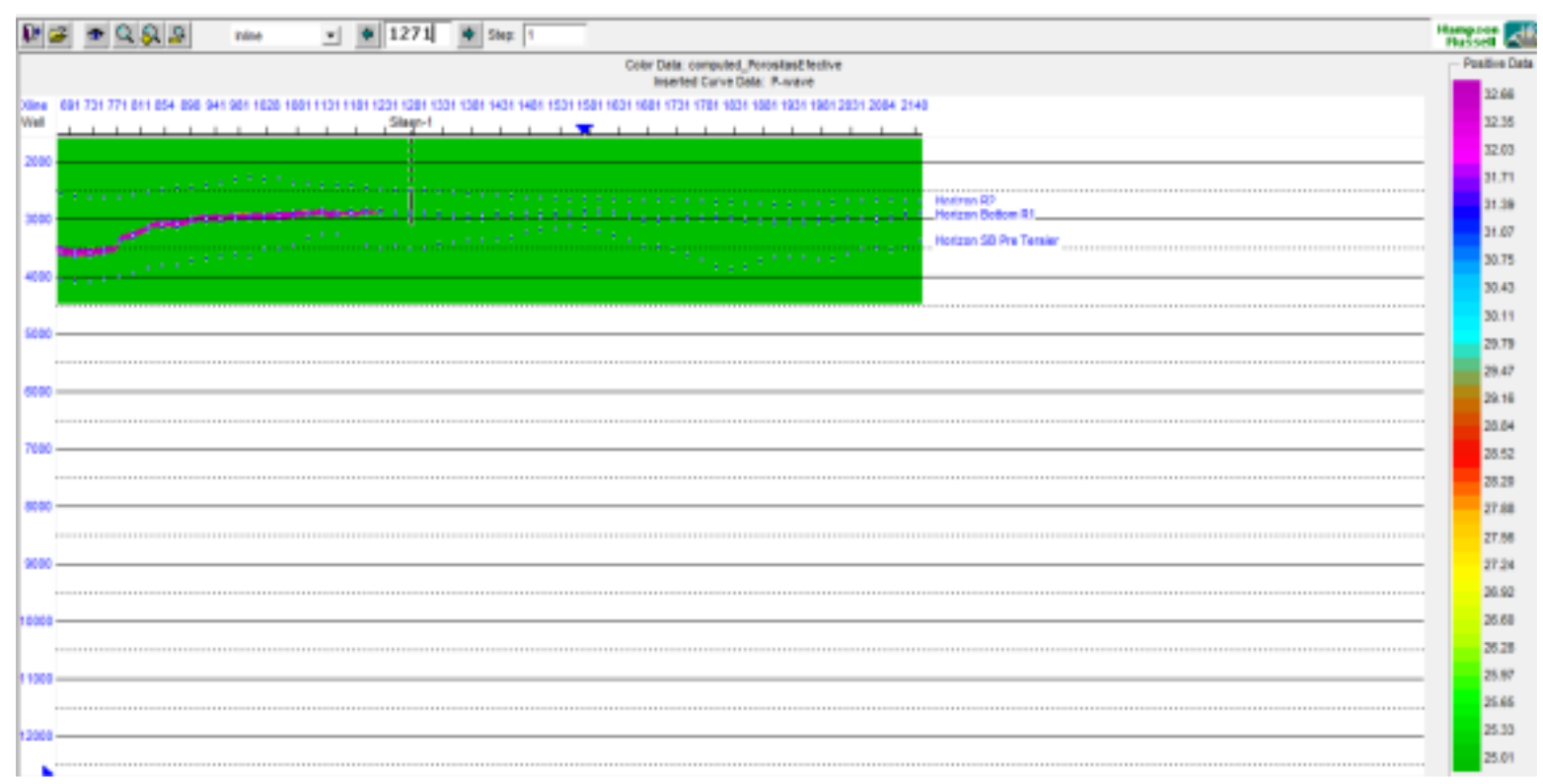

Gambar 10. Sebaran nilai porositas efektif.

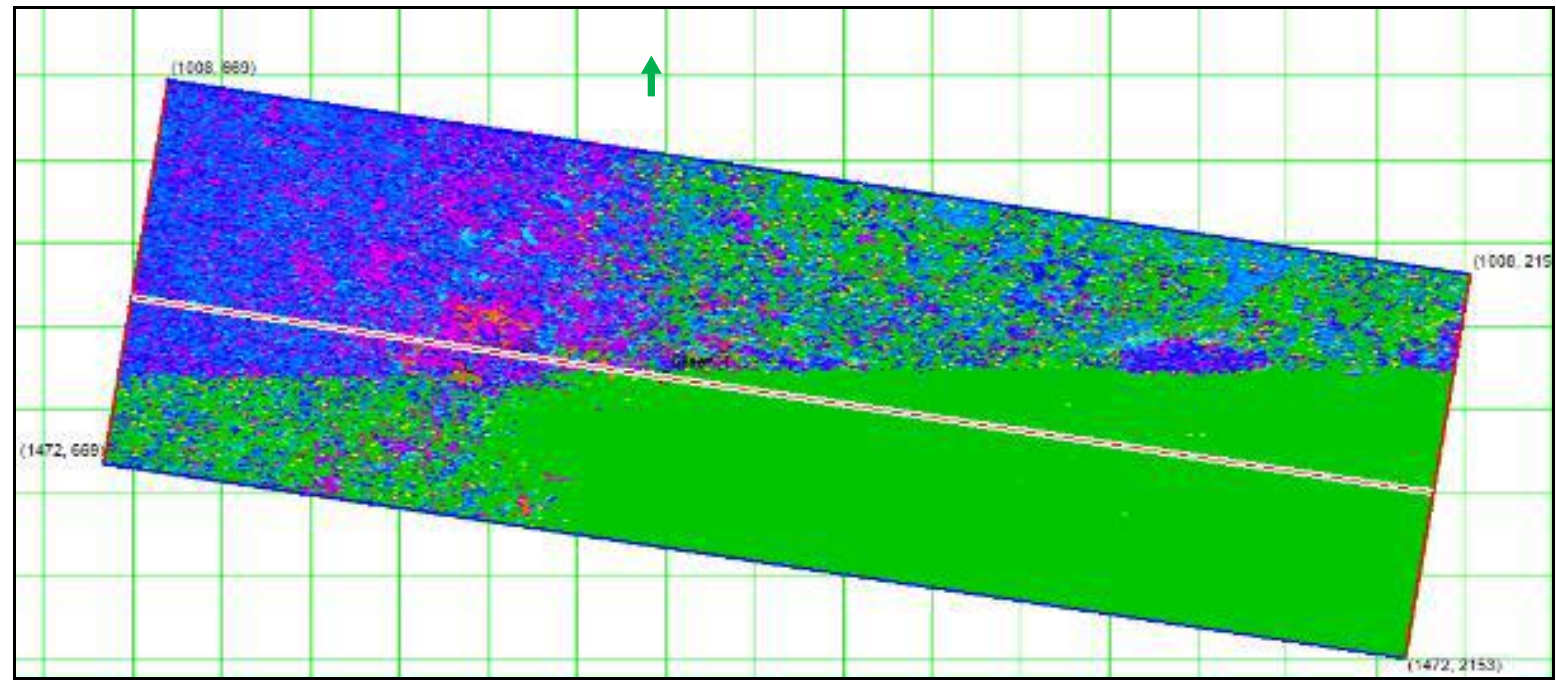

Gambar 11. Irisan sebaran porositas efektif horison R1 


\section{Inventarisasi Area Prospek}

Inventarisasi area prospek merupakan tahapan akhir dalam penelitian ini. Inventarisasi area prospek ini berdasarkan play dan keadaan porositas efektif batuan. Berdasarkan play, dari empat horison yang diindikasikan merupakan area potensi, tiga diantaranya dapat dijadikan area prospek terbaru dalam tahapan eksplorasi. Tiga horison tersebut berupa horison top R1, bottom R1, dan SB pra-tersier. Horison R2, tidak dapat dijadikan area prospek baru karena bagian antiklin sudah dilakukan pengeboran terhadap sumur Silaen-3. Sementara sepanjang horison R2, bagian antiklin hanya terdapat pada sumur yang sudah dilakukan pengeboran tersebut (Gambar 16).

Horison top R1 dan bottom R1 diasumsikan sama, karena R1 merupakan satu tubuh formasi yang sama. Ada dua lokasi yang prospek pada horison R1, yaitu R1-MS-01 (closure bagian timur) dan R1-MS-02 (closure bagian barat). Area R1 menjadi menarik untuk diteliti lebih lanjut karena sumur yang berproduksi pada area ini masih mengincar reservoir berumur Miosen yaitu pada Formasi Kujung, dan hanya beberapa sumur yang mencari reservoir hingga umur Eosen yakni pada Formasi Ngimbang klastik.

Gambar 17 menunjukkan bahwa area prospek baru tersebut dibatasi oleh adanya patahan yang menyambungkan dari area depocentre yang dapat diindikasikan bahwa hidrokarbon bermigrasi dari area tersebut sampai pada bentukan lipatan antiklin. Garis berwarna hitam tebal merupakan patahan regional penelitian yang telah dianalisis serta memiliki orientasi arah barat-timur. Jadi berdasarkan play, area prospek baru horison $\mathrm{R} 1$, terdiri dari dua area prospek terbaru, yaitu R1-MS-01 (closure bagian timur) dan R1-MS-02 (closure bagian barat).

Horison SB pra-Tersier memiliki empat area prosepek baru, yaitu MS-SBPT-01, MS- SBPT02, MS- SBPT-03, dan MS- SBPT-04 (Gambar 18, dari barat ke timur) Keterdapatan area prospek baru pada horison ini akan menarik untuk diteliti lebih lanjut karena sebelumnya tidak ada sumur yang melakukan pengeboran hingga level horison SB pra-Tersier ini. Selain itu dengan kondisi patahan mayor yang memiliki umur sama dengan pengisian sedimen pada cekungan ini menjadi daya dukung dalam melihat potensi keterdapatan jebakan hidrokarbon yang mungkin terdapat dalam horison ini. Patahan mayor itulah yang mengendapkan batuan ataupun formasi yang diindikasikan sebagai batuan sumber yakni PraNgimbang. Hal ini akan menjadi lebih menarik lagi meneliti untuk mengetahui sumber hidrokarbon sebenarnya karena masih ada batuan metasedimen berumur lebih tua daripada Tersier (Gambar 18).

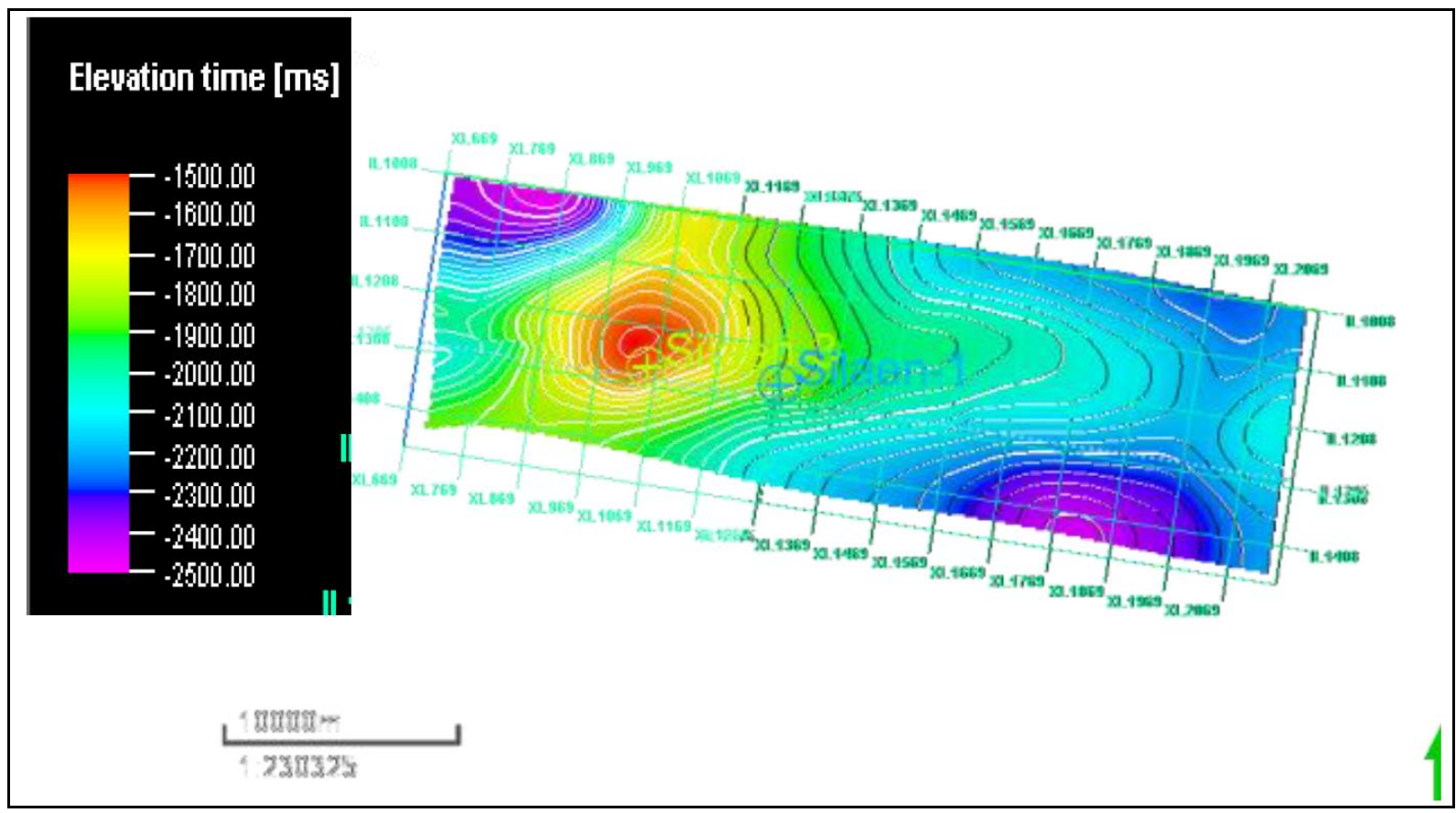

Gambar 12. Peta struktur kedalaman horison R2. 


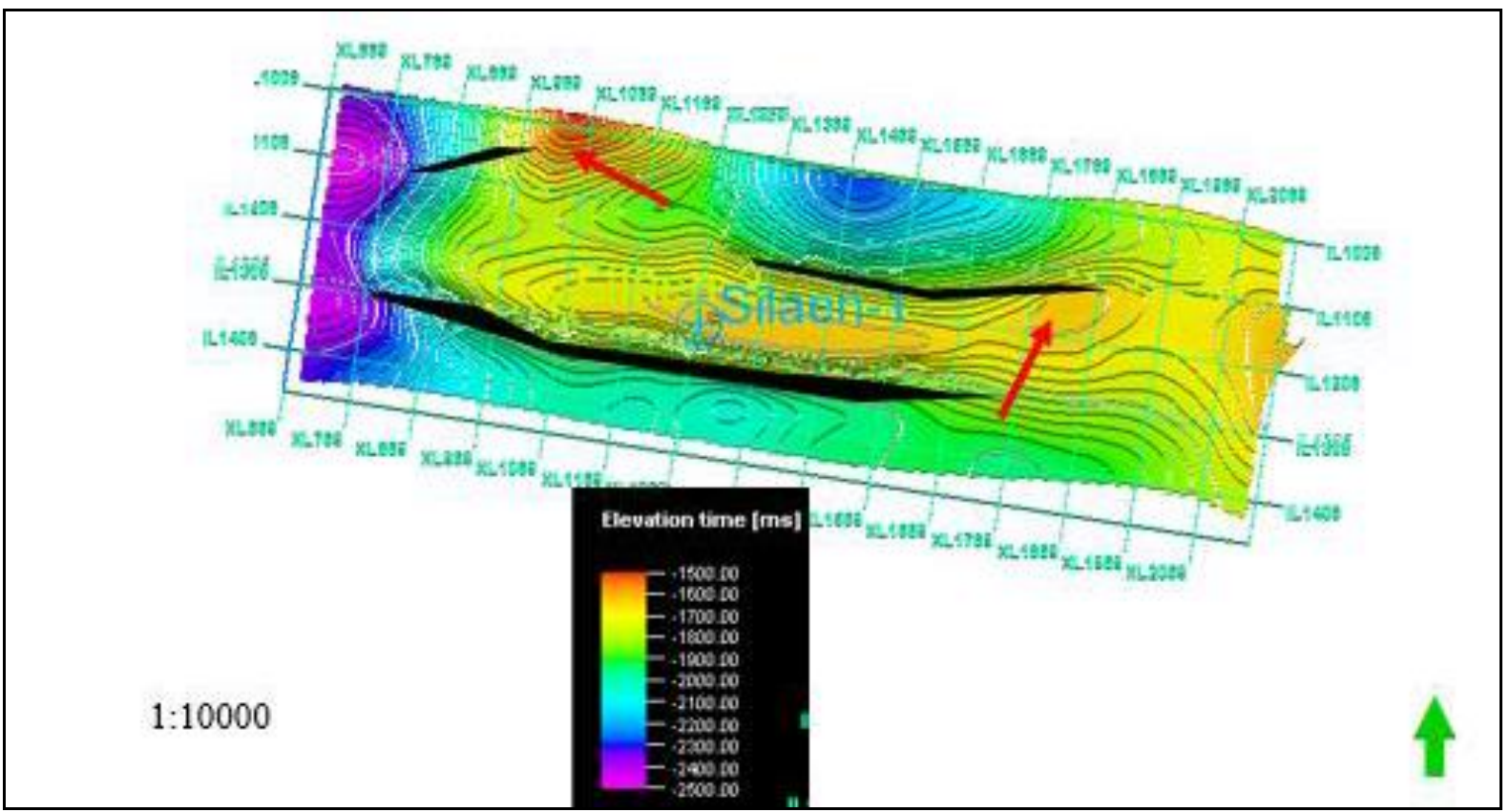

Gambar 13. Area prospek baru horison R1 berdasarkan play ditunjukkan oleh tanda panah, R1-MS-01 (closure bagian timur) dan R1-MS-02 (closure bagian barat).

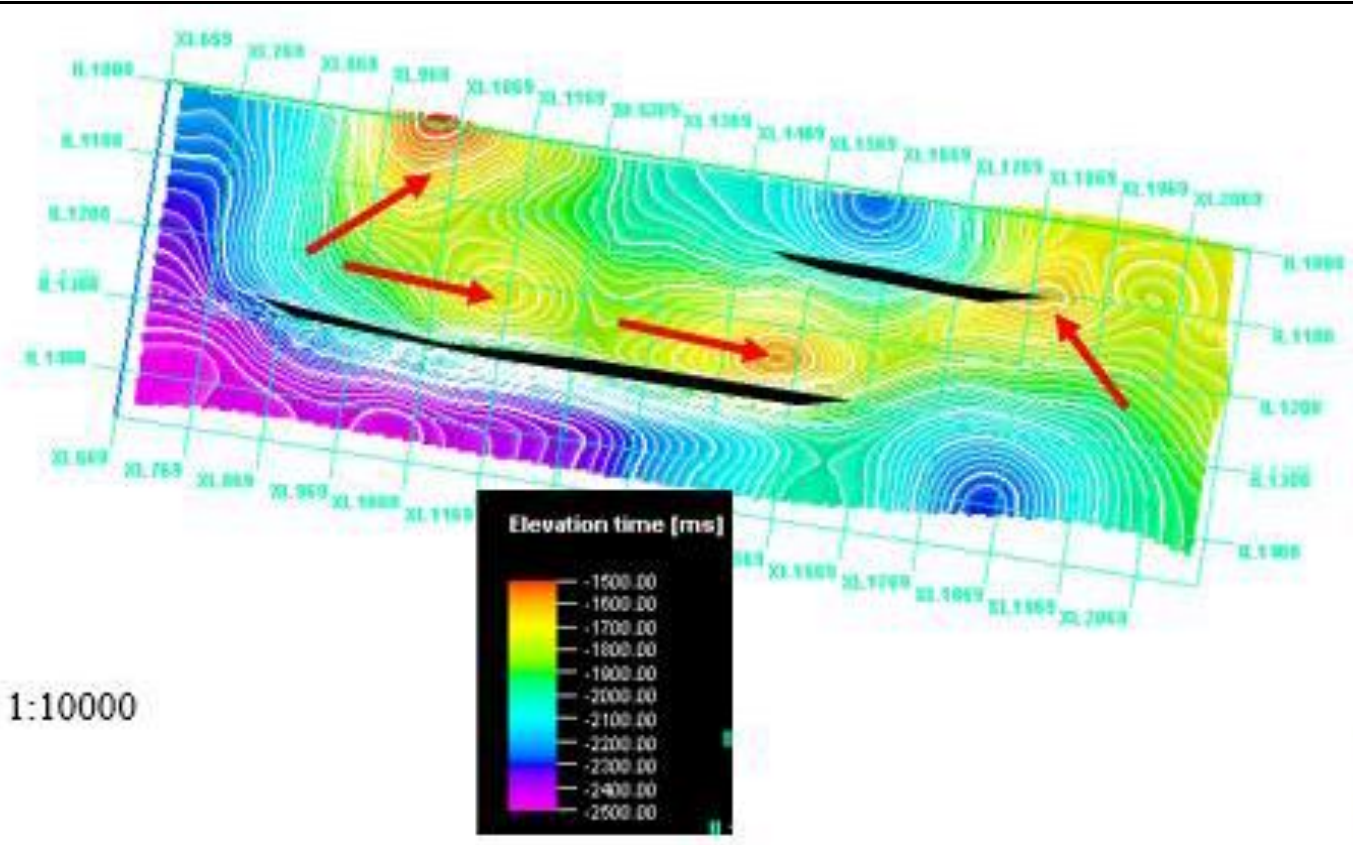

Gambar 14. Area prospek baru horison SB pra-Tersier berdasarkan play ditunjukkan oleh tanda panah (MSSBPT-01, MS- SBPT-02, MS- SBPT-03, dan MS- SBPT-04 (dari barat ke timur).

Area prospek baru pada horison SB pra tersier tersebut merupakan yang dibatasi oleh patahan terhubung dengan depocentre sebagai tempat hidrokarbon dapat bermigrasi dan dibatasi oleh bagian atas berupa bentukan antiklin agar hidrokarbon berakumulasi di antiklin tersebut. Jadi berdasarkan play, area prospek baru horison SB pra tersier terdapat empat area terbaru yang dapat ditunjukkan oleh tanda panah tersebut.

Parameter berbeda untuk mengetahui potensi reservoir berdasarkan persebaran porositas efektif. Sebaran porositas efektif dapat diketahi setelah melakukan tahapan analisis petrofisika 


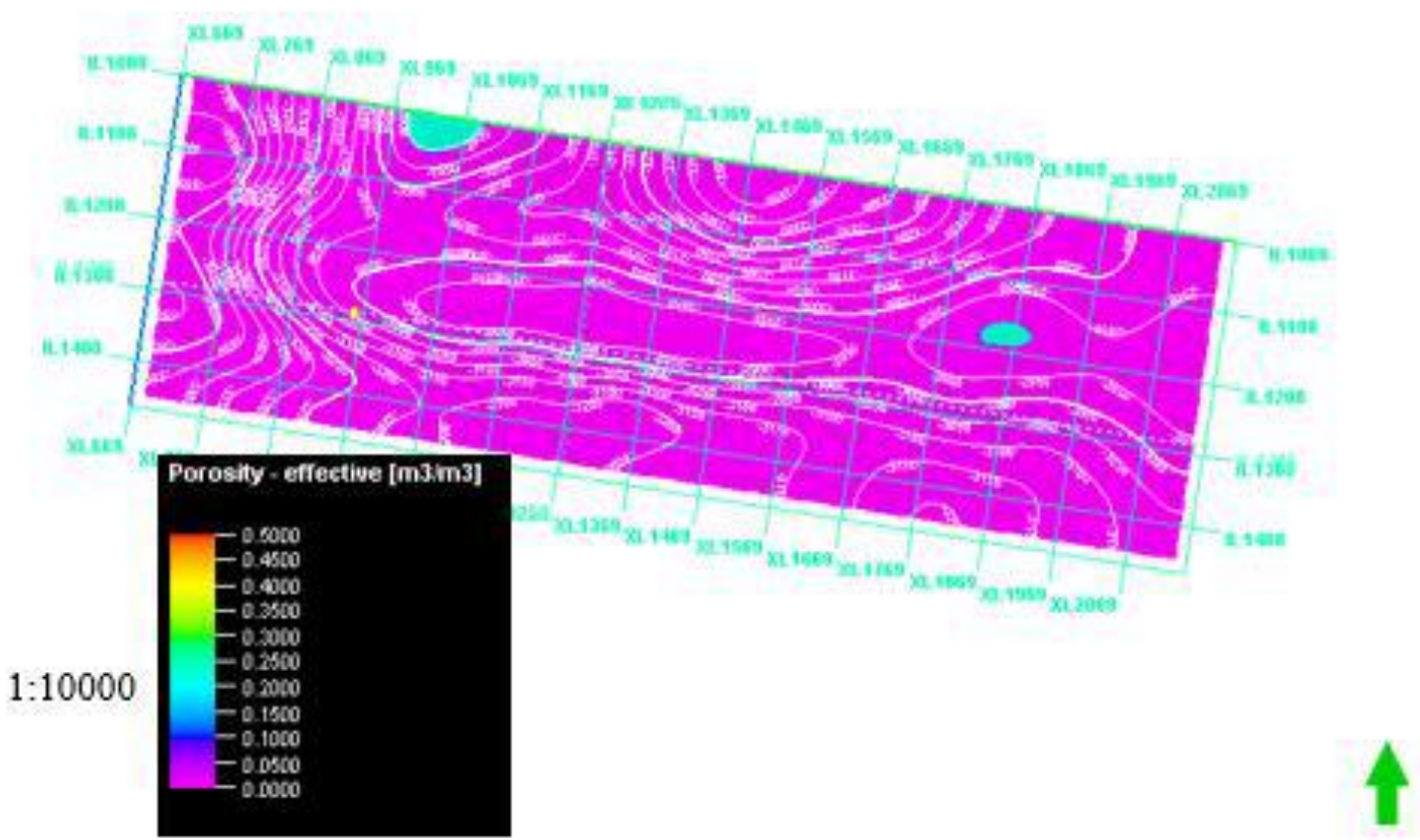

Gambar 15. Overlay peta porositas efektif dengan peta struktur kedalaman horison R1.

untuk mendapat angka propertinya. Dengan demikian, horison yang dapat dijadikan sebagai potensi reservoir berdasarkan keadaan porositas efektif yaitu hanya horison R1 karena horison SB pra tersier tidak memiliki angka properti porositas. Hasil slice sebaran porositas efektif dari analisis sebelumnya dapat dikombinasikan dengan peta struktur kedalaman horison untuk mengetahui hubungan keadaan porositas dengan keadaan geologi berupa patahan dan lipatan. Gambar 18 merupakan hasil analisis antara hubungan peta struktur kedalaman dengan persebaran porositas efektif pada horison R1.

Gambar 19 menunjukkan adanya hubungan area prospek baru horison R1 yang sudah dijelaskan sebelumnya. Area yang memiliki nilai porositas tinggi tersebut merupakan area prospek baru dan sesuai keberadaan play. Daerah yang memiliki warna lebih cerah daripada area lain, ditunjukkan oleh warna biru muda denga nilai leboh besar dari $0,1 \quad(\mathrm{v} / \mathrm{v})$, menujukkan keterdapatan porositas efektif sangat tinggi. Oleh karena itu, pada daerah tersebut potensi reservoir menjadi lebih tinggi lagi. Selain itu, dengan adanya overlay terhadap peta struktur kedalaman menunjukkan daerah tersebut merupakan daerah tutupan atau closure artinya tempat akumulasi hidrokarbon tinggi di area tersebut. Ini menjadi daya dukung dalam melakukan kegiatan eksplorasi lebih lanjut.

\section{PEMBAHASAN}

\section{Diskusi Geologi Area Penelitian}

Berdasarkan interpretasi litologi kedua sumur menggunakan pembacaan log Gamma Ray, log Density, dan log Neutron yang juga validasi dengan completion log, terdapat hasil interpretasi berupa batupasir yang memiliki karakteristik berbeda berdasarkan ukuran butiran dan komposisi.

Dari hasil interpretasi litologi pada Sumur Silaen-1, terdapat susunan litologi yang sangat beragam sehingga bila disebandingkan dengan stratigrafi regional formasi yang diteliti merupakan Formasi pra-Ngimbang dan Ngimbang.

Formasi pra-Ngimbang disusun oleh batupasir yang berseling dengan shale serta ada keterdapatan sisipan batugamping. Data completion log menunjukkan batupasir praNgimbang banyak terdapat fragmen berupa konglomerat dan kerakal, sehingga dapat diinterpretasikan batupasir tersebut merupakan produk sedimen dari darat. Kenampakan Formasi pra-Ngimbang pada seismik dibatasi oleh patahan yang terbentuk oleh aktifitas tektonik pemekaran atau rifting. Pemekaran tersebut akan membentuk daerah rendahan atau disebut sebagai graben dan tinggian atau disebut sebagai horst. Seperti diketahui bahwa sebelum terjadinya tektonik pemekaran, bagian yang 
menjadi batuan dasar Cekungan Jawa TimurUtara merupakan mikrokontinen Australia. Setelah terjadinya tektonik pemekaran menyebabkan area mikrokontinen tersebut menjadi terbagi-bagi sehingga ada yang terdapat di bagian tinggian (horst) dan rendahan (graben). Pada daerah tinggian, perlahan akan mengalami proses erosi batuan dan semakin bertambah waktu menjadi mengalami proses sedimentasi sehingga material akan tertransport pada bagian tinggian sehingga mengisi bagian rendahan yang menyebabkan material tersebut merupakan cikal bakal Formasi Pra-Ngimbang. Proses pengisian material tersebut disebut juga sebagai proses synrift karena selama terjadinya tektonik pemekaran, proses pengisian oleh material sedimen akan menempati area yang terkena tektonik pemekaran tersebut.

Menurut Prosser (1993), endapan synrift dibedakan menjadi dua jenis berdasarkan letaknya, yakni endapan synrift initiation dan synrift climax. Endapan synrift initiation merupakan endapan yang dibatasi pada patahan dan bentukannya onlap terhadap hanging wall. Endapan synrift climax merupakan endapan yang dibatasi yang terbentuk karena laju perpindahan patahan bernilai maksimum dan bentukannya dicirikan bagian reflector yang mendekat pada footwall. Berdasarkan analisis kedalaman oleh data sumur, kenampakan pada seismik, Formasi Pra-Ngimbang diendapkan pada lingkungan pengendapan alluvial. Analisis kedalaman dilakukan dengan melihat nilai kedalaman yang ada di data log. Gambar 20 menunjukkan kenampakan pada seismik dan hubungannya dengan kondisi lingkungan pengendapan pada Formasi Pra-Ngimbang.

Berbeda dengan susunan litologi Formasi Pra-Ngimbang, Formasi Ngimbang dicirikan dengan keterdapatan susunan litologi shale yang sangat dominan dengan ada sisipan batubara. Pada suatu keadaan, terdapat endapan batupasir yang menebal diantara shale. Keadaan tersebut dapat mencirikan fasies pengendapan berupa channel. Gambar 20 menunjukkan endapan channel pada susunan stratigrafi berdasarkan analisis data log pada Formasi Ngimbang.

Berdasarkan analisis kenampakan data log, kenampakan seismik, dan biostratigrafi, Formasi Ngimbang terendapkan di eustuarin pada fasies Channel. Perbedaan antara sistem pengendapan eustuarin dengan delta ialah proses sedimentasi, yang mana pada sistem pengendapan delta didominasi oleh suplai sedimen, sehingga pengendapan delta cenderung mengarah pada laut, sedangkan pada eustarin didominasi oleh ruang akomodasi oleh laut yang menyebabkan dominasi oleh sedimen halus dari laut berupa shale.

Adanya keterdapatan sisipan batubara dan batupasir pada sistem Eusturain ini merupakan pengaruh kontrol dari sistem sungai yang memotong bentukan Eustuarin dan membawa material batubara serta batupasir, sehingga pengendapannya akan bersamaan dengan shale tersebut. Selain itu, proses sikuen yang terjadi pada lingkungan pengendapan Eustuarin, yaitu

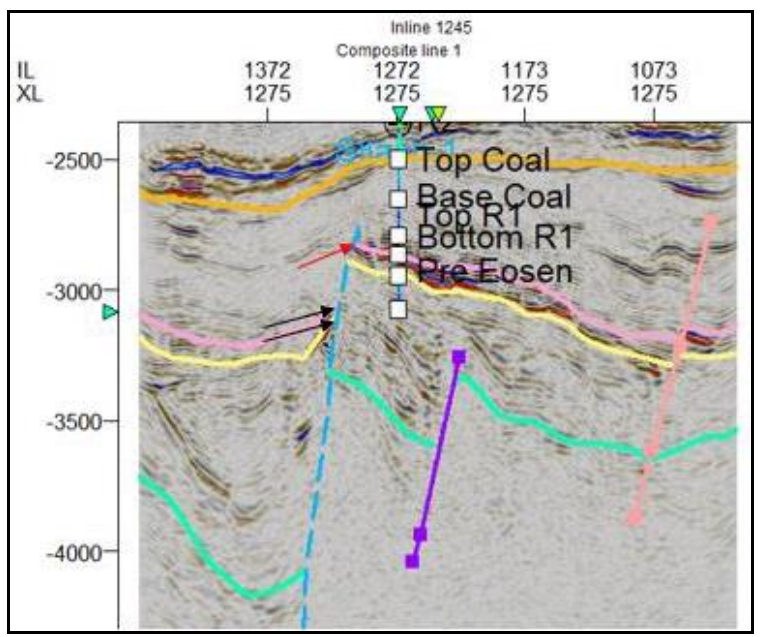

Gambar 16. Rifting initiation (panah warna hitam) dan climax (panah berwarna merah).

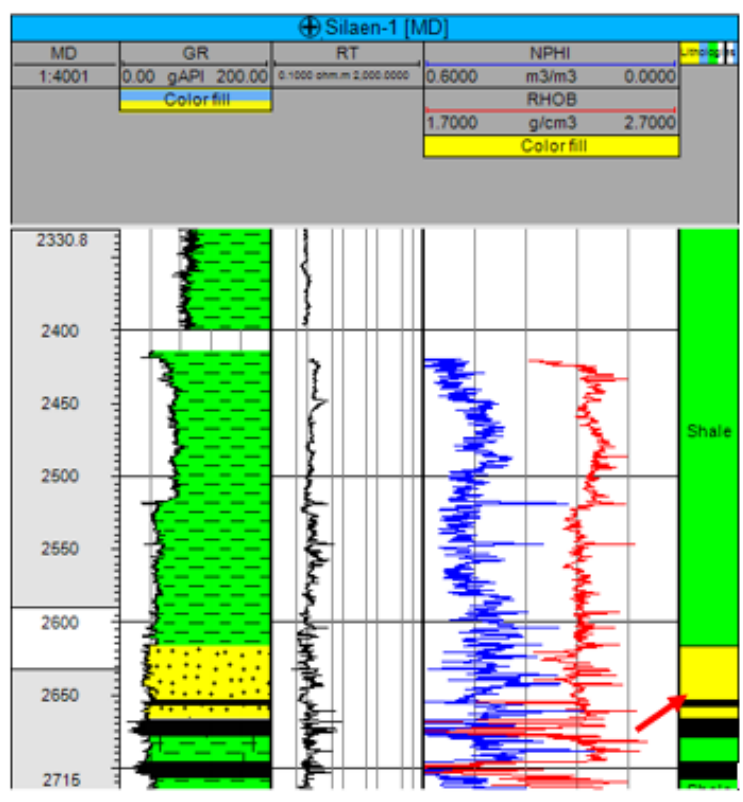

Gambar 17. Fasies channel pada Formasi Ngimbang, Sumur Silaen-1, ditunjukkan panah merah. 
permukaan air laut relatif yang berpengaruh terhadap ruang akomodasi. Permukaan air laut relatif yang terjadi merupakan permukaan air yang naik, sehingga menyebabkan dominasi oleh sedimentasi dari laut menuju darat. Proses tersebut banyak menyebabkan pengendapan material halus berupa shale pada kondisi tersebut. Suplai sedimen dari darat masih juga berlangsung, sehingga dapat mengendapkan berupa batupasir dan juga batubara. Gambar 21 memperlihatkan bahwa sistem pengendapan eustari berupa fasies channel berperan penting dalam mengendapkan litologi berupa batupasir yang nantinya akan sebagai reservoir dalam sistem petroleum. Batupasir dengan keterdapatan porositas tinggi akan membuat kualitas semakin baik lagi. Porositas tinggi dari batupasir didapatkan dari hasil sedimentasi di material sedimen di lingkungan channel. Persebaran nilai porositas tinggi (Gambar 19), menunjukkan nilai porositas tersebut berada di sepanjang channel (Gambar 17 dan 18).

\section{KESIMPULAN}

Susunan stratigrafi yang diteliti terdiri atas Formasi pra-Ngimbang-Ngimbang, yang memiliki penciri satuan litologi berupa batupasir. Formasi yang dijadikan dalam target penelitian adalah metasedimen Mesozoikum dan Formasi pra-Ngimbang-Ngimbang. Struktur geologi regional hasil penelitian berupa sesar normal yang bersifat mayor dan memiliki orientasi arah barat-timur.

Area yang diindikasikan sebagai tempat akumulasi hidrokarbon pada sumur Silaen-1 berada di kedalaman 2.800-2.990 m, sedangkan sumur Silaen-3 berada di kedalaman 2.900$3.180 \mathrm{~m}$. Nilai rata-rata parameter petrofisika pada zona reservoir yakni, porositas efektif memiliki rerata nilai pada sumur Silaen-1 sebesar 0,27 sumur Silaen-3 sebesar 0,24. Nilai rerata volume serpih pada sumur Silaen-1 sebesar 0,23 sedangkan sumur Silaen-3 memiliki nilai sebesar 0,05 . Nilai saturasi air pada sumur Silaen-1 memiliki rerata sebesar 0,90 sedangkan sumur Silaen-3 sebesar 0,8.

Berdasarkan keterdapatan play, ada tiga horison yang dapat dijadikan sebagai zona potensi baik yaitu horison top R1, bottom $\mathrm{R} 1$, dan SB pra-tersier, namun $\mathrm{R} 1$ diasumsikan sebagai satu horison karena R1 merupakan satu tubuh formasi yang sama. Horison R1 terdapat dua area prospek terbaru, yaitu R1-MS-01 (closure bagian timur) dan R1-MS-02 (closure bagian barat), sedangkan horison SB pra-tersier terdapat empat area propek terbaru, yaitu MSSBPT-01, MS- SBPT-02, MS- SBPT-03, dan MS- SBPT-04. Adanya parameter persebaran porositas efektif hanya dilakukan pada horison R1 karena data sumur tidak mencapai horison SB pra-tersier. Dengan persebaran porositas efektif tersebut dapat menguatkan argumen area prospek baru.

\section{UCAPAN TERIMA KASIH}

Penulis mengucapkan ucapan terima kasih, kepada EASCO East Sepanjang yang membantu dalam menyediakan data dan perijinan terkait publikasi.

\section{DAFTAR PUSTAKA}

Doust, H. dan Noble, A. R., 2008, Petroleum system of Indonesia. Marine and Petroleum Geology, 25(2), 103-129.

Emmet, P.A. dan Bally, A.W., 1996, Evolution of Cenozoic inversion structures, East Java Sea, Indonesia.. Abstrak. San Diego: American Association of Petroleum Geologists Meeting.

Maulin, H., B., Armandita, C., Mukti, M., Mandiri, D., Rubyanto, J., Romi, S., 2012. Structural Reactivation and Its Implication on Exploration Play: Case Study of JS-1 Ridge. Proceeding of Indonesian Petroleum Association 36th Annual Convention.

Philips, T.L., Noble, R.A., dan Sinarto, F.F., 1991. Origin of Hydrocarbons, Kangean Block Northersn Platform, Offshore N.E. Java Sea. Proceeding of Indonesia Petroleum Association 20th Annual Convention, P.637661.

Prosser, S., 1993. Rift-related linked depositional systems and their seismik expression, in G. D. Wouldiams and A. Dobb, eds., Tectonics and seismik sequence stratigraphy: Geological Society Special Publication, 71, hal.35-66.

Satyana, A., H., 2016, The Emergence of PreCenozoic Petroleum System In East Java Basin: Constraints From New Data And Interpretation Of Tectonic Reconstruction, Deep Seismik, and Geochemistry. Proceeding of Indonesian Petroleum Association 40th Annual Convention, P. 16573. 
Sribudiyani, Muschin, N., Ryacudu, R., Kunto, T., Astono, P., Prasetya, I., Sapiie B., Asikin, S., Harsolumakso, H.A., dan Yulianto, I., 2003. The Collision of The East Java
Microplate and Its Implication for Hydrocarbon occurrences in the East Java Basin. Proceeding of Indonesian Petroleum Association 29th Annual Convention. 